\title{
KLASIFIKASI SENTRA INDUSTRI PERIKANAN BERBASIS PELABUHAN PERIKANAN: KASUS DI KABUPATEN BELITUNG
}

\author{
Marwan Syaukani'1), Muhammad Fedi Alfiadi Sondita'2), Daniel Monintja²), \\ Akhmad Fauzi's), dan Victor Petrus Hiliary Nikijuluw ${ }^{4)}$ \\ ${ }^{1)}$ Mahasiswa pada Fakultas Perikanan dan Ilmu Kelautan-Institut Pertanian Bogor, Bogor \\ ${ }^{2)}$ Dosen pada Fakultas Perikanan dan IImu Kelautan-Institut Pertanian Bogor, Bogor \\ ${ }^{3)}$ Dosen pada Fakultas Ekonomi dan Manajemen-Institut Pertanian Bogor, Bogor \\ 4)Peneliti pada Sekretariat Direktorat Jenderal Pengelolaan dan Pemasaran Hasil Perikanan, Jakarta \\ Teregristrasi I tanggal: 9 April 2010; Diterima setelah perbaikan tanggal: 20 April 2010; \\ Disetujui terbit tanggal: 30 April 2010
}

\begin{abstract}
ABSTRAK
Klasifikasi pelabuhan perikanan Indonesia yang terdiri atas Pelabuhan Perikanan Samudera, Pelabuhan Perikanan Nusantara, Pelabuhan Perikanan Pantai, dan Pusat Pendaratan Ikan. Klasifikasi tersebut di atas didasari hubungan inti plasma di mana pelabuhan perikanan yang besar ditunjang beberapa pelabuhan perikanan yang lebih kecil (Direktorat Jenderal Perikanan Tangkap, 2008). Hubungan inti plasma tersebut tidak berjalan karena tidak mempunyai pola hubungan yang jelas. Oleh sebab itu diperlukan alternatif klasifikasi pelabuhan perikanan dengan memasukan unsur jaringan industri seperti yang diusulkan oleh Israel \& Rouqe (2000) yang mengklasifikasikan pelabuhan perikanan menjadi tiga yaitu penyedia jasa utama, penyedia jasa antara (server), dan client. Penelitian ini bertujuan menentukan klasifikasi sentra industri perikanan berbasis pelabuhan perikanan dalam jaringan industri yang efektif dan efisien dilakukan di Kabupaten Belitung selama 11 bulan sejak Oktober 2007 sampai Agustus 2008. Metode yang dipergunakan adalah multi criteria analysis yang dilanjutkan dengan analisis technique for order preference by similarity to ideal solution. Parameter yang diukur meliputi infrastruktur pelabuhan perikanan, kapasitas kapal perikanan, kemandirian faktor input, dan produksi. Hasil penelitian menunjukan bahwa Pulau Belitung berperan sebagai penyedia jasa utama, Pulau Mendanau, dan Pulau Seliu berperan sebagai penyedia jasa antara (server), dan Pulau Gersik dan Pulau Sumedang berperan sebagai client. Klasifikasi pelabuhan perikanan dalam suatu jaringan industri berimplikasi pada peningkatan efektivitas dan efisiensi pembangunan pelabuhan perikanan tangkap sebagai sentra industri perikanan tangkap.
\end{abstract}

KATAKUNCI: industri perikanan tangkap, wilayah kepulauan, multi criteria analysis, technique for order preference by similarity to ideal solution, Belitung

ABSTRACT: Classification of fishing industrial center based on fishing port: Belitung Regency case. By: Marwan Syaukani, Muhammad Fedi Alfiadi Sondita, Daniel Monintja, Akhmad Fauzi, and Victor Petrus Hiliary Nikijuluw

Indonesian government classify fishing port into 4 categories namely Ocean Fishing Port, National Fishing Port, Sea Shore Fishing Port, and Fish Landing Fishing Port. The above classification based on partnership or lingkage industry 
among fishing ports. However, the lingkage industry do not run effectively due to unappropriate pattern. Improving the condition, Israel \& Roque (2000) suggested to classify fishing port into 3 categories namely main service provider, intermediate service provider or server, and client. This paper describes an alternative formula that considers industrial linkage among fishing ports as fishing industrial centers. The research was held on Belitung Regency as long as 11 months from October 2007 to August 2008. There are several factors should be considered in building fishing port namely fishing facilities, fishing capacity, input dependency and fish landing capacity. The 4 factors are analyzed by multi criteria analysis then continued by technique for order preference by similarity to ideal solution analysis. The research concludes that the Belitung is as the main service provider, the Mendanau Island and Seliu Islands are as the intermediate service provider or server, the other 2 islands are as the client. The new classification will increase effectiveness and efficiency of fishing port developments.

KEYWORDS: fishing industry, archipelagic, multi criteria analysis, technique for order preference by similarity to ideal solution, Belitung

\section{PENDAHULUAN}

Sebagai negara kepulauan yang luas dan menyebar, negara Indonesia belum mempunyai alternatif modal transportasi yang bersifat massal. Transportasi udara tidak dapat diandalkan sebagai alat transportasi industri perikanan tangkap, karena biayanya mahal dan tidak dapat mengangkut komoditi secara massal. Pilihan yang paling memungkinkan adalah angkutan laut. Namun kenyataannya biaya transportasi laut pun relatif mahal.

Secara umum, terdapat dua model pengembangan pelabuhan perikanan sebagai sentral industri yaitu HUB dan Point model (Robinson, 2003). HUB model adalah sentra industri perikanan tangkap berbasis pelabuhan perikanan yang didukung oleh beberapa pelabuhan perikanan kecil lain, sedangkan Point model adalah pembangunan sentra industri perikanan berbasis pelabuhan perikanan yang berfungsi sebagai sentra industri perikanan tangkap bagi pelabuhan itu sendiri. Klasifikasi pelabuhan perikanan tangkap di Indonesia yang dikembangkan oleh Direktorat Jenderal Perikanan Tangkap pada hakekatnya didasari oleh hubungan inti plasma seperti pada HUB model. Pelabuhan Perikanan Samudera Jakarta merupakan contoh HUB model di mana Pelabuhan Perikanan Samudera Jakarta merupakan sentral beberapa pelabuhan kecil lain seperti Pelabuhan Perikanan Nusantara Pelabuhan Ratu dan Pelabuhan Perikanan Nusantara Pekalongan. Namun hubungan inti plasma ini tidak diaplikasikan di seluruh pelabuhan perikanan. Beberapa pelabuhan seperti Pelabuhan Perikanan Samudera Belawan, Pelabuhan Perikanan Samudera Bungus, dan Pelabuhan Perikanan Nusantara Tanjung Pandan merupakan contoh pelabuhan perikanan yang dibangun mengacu pada hubungan inti plama, namun pada realisasinya mengaplikasikan Point model. Fenomena ketidak-jelasan fungsi mengakibatkan biaya transportasi menjadi mahal. Sehubungan dengan hal di atas, Israel \& Rouqe (2000) mengusulkan alernatif pembangunan jaringan industri perikanan tangkap di wilayah melalui pengembangan model $H U B$ dengan mengklasifikasi sentra industri perikanan berbasis pelabuhan perikanan sebagai penyedia jasa utama, penyedia jasa antara, dan client. 
Penelitian tentang jaringan pelabuhan umum maupun perikanan telah banyak dilakukan oleh beberapa pakar antara lain jaringan Pelabuhan Selat Gibraltar oleh Hadi \& Moron (2007), jaringan Pelabuhan Korea Selatan, Cina, dan Jepang oleh Yang et al. (2005); Wang (2007), dan jaringan Pelabuhan Asia Timur oleh Tai \& Hwang (2005). Penelitian di atas pada umumnya memfokuskan hubungan industri antar suatu wilayah dengan wilayah kontinental. Sedangkan penelitian ini memfokuskan pada memformulasikan jaringan industri yang disesuaikan dengan kondisi wilayah kepulauan yang ada di Indonesia. Penelitian ini bertujuan menentukan klasifikasi lima sentra industri perikanan berbasis pelabuhan perikanan yang ada di Kabupaten Belitung dalam jaringan industri perikanan tangkap yang efektif dan efisien.

\section{BAHAN DAN METODE}

\section{Waktu dan Tempat}

Penelitian ini dilakukan selama 11 bulan dari bulan Oktober 2007 sampai Agustus 2008 di lima pulau utama di Kabupaten Belitung yaitu Pulau Belitung dengan fokus di Pelabuhan Perikanan Nusantara Tanjung Pandan, Pulau Mendanau dengan fokus Pusat Pendaratan Ikan Selat Nasik, Pulau Gersik, Pulau Seliu, dan Pulau Sumedang (Gambar 1).

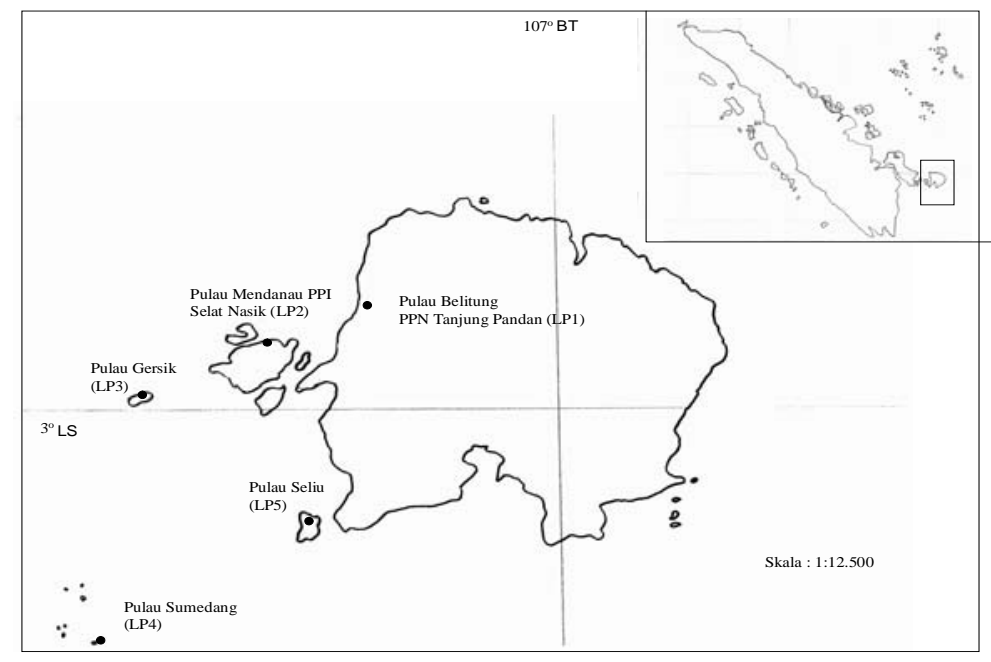

Gambar 1. Peta lokasi penelitian meliputi Pulau Belitung, Pulau Mindanau, Pulau Gersik, Pulau Sumedang, dan Pulau Seliu.

Figure 1. Map of study sites include the Island of Belitung, Island of Mindanao, the island of coarse sand, Sumedang Island, and Island Seliu.

\section{Instrument Pendukung}

Ketersediaan alat pendukung merupakan hal yang sangat diperlukan dalam melakukan penelitian. Pada penelitian ini peralatan yang digunakan di antaranya kuisioner sebagai pedoman pengumpulan data, alat tulis, alat ukur, komputer untuk rekapitulasi dan analisis data, dan kamera untuk kepentingan dokumentasi penelitian. 


\section{Data dan Metode Pengumpulan Data}

Data primer dan data sekunder digunakan dalam penelitian ini. Pengumpulan data primer dilakukan melalui metode survei yaitu pengamatan langsung terhadap aktivitas perikanan dan wawancara dengan pelaku bisnis perikanan yang dikelompokan dalam empat kelompok, yaitu pembina nelayan, nelayan, pengusaha pengangkutan ikan, dan pengolah hasil perikanan. Wawancara dilakukan terhadap tiga pembina nelayan di masing-masing lokasi penelitian, 32 nelayan kapal penangkap ikan dengan kapasitas d" 5 sampai e" $10 \mathrm{GT}$, tiga pengusaha pengangkut hasil perikanan, dan enam pengolah hasil perikanan (cold storage). Informasi yang dikumpulkan dari masingmasing contoh disajikan pada Tabel 1.

Tabel 1. Klasifikasi responden, jenis data, dan teknik pengumpulan data

Table 1. Classification of respondents, types of data, and data collection techniques

\begin{tabular}{ccccc}
\hline No. & $\begin{array}{c}\text { Pelaku bisnis } \\
\text { perikanan/ } \\
\text { Business } \\
\text { people } \\
\text { fishery }\end{array}$ & $\begin{array}{c}\text { Jumlah } \\
\text { contoh/ } \\
\text { Total } \\
\text { sample }\end{array}$ & $\begin{array}{c}\text { Uraian data yang dikumpulkan/ } \\
\text { Description of data collected }\end{array}$ & $\begin{array}{c}\text { Teknik } \\
\text { pengumpulan } \\
\text { datal }\end{array}$ \\
\hline 1 & 2 & 3 & 4 & $\begin{array}{c}\text { Data collection } \\
\text { techniques }\end{array}$ \\
\hline
\end{tabular}

\section{Produksi}

1. Pembina nelayan

2. Nelayan

\section{Pengolahan dan pemasaran}

1. Pengusaha cold storage

2. Pengusaha pengangkutan ikan
Kepemilikan kapal, jumlah kapal danWawancara nelayan binaan, mekanisme pembiayaan, bagi hasil usaha, biaya operasional, dan biaya tetap.

32 Spesifikasi teknis unit penangkapan: Pengukuran

a. Ukuran, bahan, dan alat tangkap. dan wawancara

b. Bobot kapal dan permesinan.

c. Metode operasi.

d. Lama trip dan jumlah trip per tahun.

e. Jumlah anak buah kapal

Biaya operasional, pendapatan anak buah kapal, bagi hasil, dan proses penanganan.

6 Mekanisme pengumpulan bahanWawancara baku, mekanisme pembayaran, spesifikasi produk yang diolah, kapasitas, daerah pemasaran, komponen biaya, produksi, dan pendapatan per tahun.

3 Spesifikasi teknik kapal: Wawancara

a. Bobot kapal.

b. Kapasitas.

c. Lama trip.

d. Jumlah trip per tahun.

Biaya tarif angkut, mekanisme pembayaran, biaya operasional, bagi hasil, dan pendapatan anak buah kapal. 
Data sekunder yang dikumpulkan berupa laporan-laporan resmi yang dipublikasikan atau yang tidak dipublikasikan meliputi:

1. Geofisik, demografi, jumlah kapal, dan produksi.

2. Produk domestik bruto daerah.

3. Rumah tangga nelayan, kapal dan alat tangkap, produksi, serta sarana dan prasarana.

4. Kebutuhan solar dan jumlah kapal.

5. Data bulanan pengiriman ikan Kabupaten Belitung.

6. Infrastruktur dan produksi ikan di Pelabuhan Perikanan Nusantara Tanjung Pandan.

\section{Teknik Analisis Data}

Analisis data dilakukan dengan menggunakan metode analisis multi criteria analysis dan technique for order preference by similarity to ideal solution analisis. Multi criteria analysis adalah metode pengambilan keputusan secara komprehensif terhadap beberapa parameter yang heterogen atau alternatif proyek. Parameter yang dianalisis pada penelitian meliputi indeks pelayanan fasilitas pelabuhan perikanan, indeks kapasitas kapal perikanan, indeks kemandirian, dan kapasitas sentra industri. Keempat parameter di atas kemudian dilakukan scoring yang nilainya antara 0-1. Hasil scoring akan tersusun sebuah matriks multi criteria analysis yang berdimensi $5 \mathrm{X} 4$. Technique for order preference by similarity to ideal solution adalah teknik penyusunan ranking terhadap parameter yang mempunyai data yang sangat bervariasi melalui penyederhanaan data sehingga variasi data relatif kecil. Matriks analisis multi criteria analysis (berdimensi 5X4) yang mempunyai elemen dengan variasi sangat besar kemudian dilakukan analisis technique for order preference by similarity to ideal solution menghasilkan ranking daripada sentral industri. Sentra industri yang mempunyai ranking tinggi berfungsi sebagai penyedia jasa utama, sentra industri yang mempunyai ranking sedang namun memiliki nilai positif pada indeks pelayanan fasilitas pelabuhan perikanan dan indeks kapasitas kapal perikanan berfungsi sebagai server, dan sentra industri yang mempunyai ranking rendah mempunyai fungsi sebagai client (Tabel 2). Asumsi yang dipergunakan adalah keempat parameter mempunyai andil yang sama dalam penentuan klasifikasi sentra industri.

Tabel 2. Klasifikasi sentra industri berbasis pelabuhan perikanan

Table 2. Classification of fishery port based industrial centers

\begin{tabular}{|c|c|}
\hline $\begin{array}{c}\text { Klasifikasi sentra industril } \\
\text { Classification of industrial centers }\end{array}$ & Kriteria/Criteria \\
\hline Penyedia jasa utama & Nilai tertinggi \\
\hline Server & $\begin{array}{l}\text { Nilai positif pada indeks pelayanan fasilitas } \\
\text { pelabuhan perikanan dan indeks kapasitas kapal } \\
\text { perikanan }\end{array}$ \\
\hline Client & Nilai rendah \\
\hline
\end{tabular}




\section{Parameter yang Dianalisis}

\section{Multi criteria analysis}

Multi criteria analysis adalah metode pengambilan keputusan terhadap beberapa alternatif proyek atau beberapa parameter. Parameter yang diukur meliputi:

1. Indeks pelayanan fasilitas pelabuhan perikanan

Indeks pelayanan fasilitas pelabuhan perikanan adalah ukuran ketersediaan fasilitas prasarana pada sentra industri perikanan tangkap. Prasarana yang diukur meliputi fasilitas pokok, yaitu dermaga, tempat pelelangan ikan, fasilitas bahan bakar minyak, pabrik es, dan fasilitas penunjang berupa cold storage. Formula untuk menghitung indeks pelayanan fasilitas pelabuhan perikanan adalah:

$$
\begin{aligned}
& \operatorname{IPFP}_{i}=\sum_{j=1}^{5} \mathrm{I}_{i j} \\
& \text { di mana: } \\
& \mathrm{I}_{\mathrm{ij}}=\mathrm{X}_{\mathrm{ij}} \mathrm{B}_{\mathrm{j}} \quad \mathrm{B}_{\mathrm{j}}=\mathrm{n}_{\mathrm{j}} / \mathrm{n} \\
& \text { IPFP }_{\mathrm{i}}=\text { indeks pelayanan fasilitas } \\
& \mathrm{B}_{\mathrm{j}} \quad=\text { bobot prasarana } \mathrm{j} \\
& \mathrm{n}_{\mathrm{j}} \quad=\text { jumlah prasarana } \mathrm{j} \\
& \mathrm{n}=\text { jumlah prasarana } \\
& \mathrm{i} \quad=\text { lokasi } \\
& \text { j = jenis prasarana }
\end{aligned}
$$

\section{Indeks kapasitas kapal perikanan}

Indeks kapasitas kapal perikanan adalah ukuran kapasitas kapal perikanan pada sentra industri perikanan tangkap dalam melakukan proses produksi. Kapal perikanan yang diamati dan dibatasi hanya pada kapal perikanan yang melakukan kegiatan penangkapan ikan. Kapasitas kapal perikanan diukur berdasarkan atas daya tampung rata-rata palka. Tiga jenis kapal yang dijadikan pengamatan adalah kapal perikanan yang berukuran kurang dari 5 GT dengan rata-rata kapasitas palka 1,2 ton, kapal yang berukuran antara 5-10 GT dengan rata-rata kapasitas palka 2 ton dan kapal yang berukuran di atas 10 GT dengan rata-rata kapasitas palka 4 ton. Formula untuk menghitung indeks armada penangkapan ikan adalah:

$$
\mid K A P I_{i}=J_{k=1}^{3}
$$

di mana:

$$
\begin{aligned}
& \mathrm{J}_{\mathrm{ik}}=\mathrm{Y}_{\mathrm{ik}} \mathrm{C}_{\mathrm{k}} \quad \mathrm{C}_{\mathrm{k}}=\mathrm{m}_{\mathrm{k}} / \mathrm{m} \\
& \mathrm{IKAPI}_{\mathrm{i}}=\text { indeks } \text { kapasitas } \text { kapal }
\end{aligned}
$$

3. Indeks kemandirian

Indeks kemandirian adalah ukuran ukuran kemampuan sentra industri perikanan tangkap untuk memenuhi kebutuhan faktor input sendiri. Faktor input yang dianalisis adalah bahan bakar minyak dan es. Nilai ini diukur berdasarkan atas proporsi (\%) faktor input, yaitu dengan rumus: 
<smiles>[Y][IH][Te]</smiles>

$$
I K_{\mathrm{II}}=\mathrm{I}_{\mathrm{I}} / \mathrm{D}_{\mathrm{I}}
$$

di mana:

$$
\begin{aligned}
& \mathbb{I K}_{\mathrm{i}}=\text { tingkat kemandirian lokasi } \mathrm{ke}-\mathrm{i} \\
& \mathrm{IK}_{\mathrm{II}}=\text { tingkat kemandirian input I pada } \\
& \quad \text { lokasi ke-i } \\
& I_{1}=\text { volume pasokan faktor input } \mathrm{I} \\
& D_{1}=\text { volume kebutuhan faktor input I } \\
& \mathrm{i}^{=}=\text {lokasi } \\
& \mathrm{I}=\text { jenis faktor input }
\end{aligned}
$$

\section{Kapasitas sentra industri}

Kapasitas sentra industri adalah volume ikan yang diproduksi dari suatu sentra industri. Kapasitas sentra industri dihitung dengan rumus sebagai berikut:

$$
\begin{aligned}
& \text { n } \\
& \underset{0=1}{\mathrm{KSI}}=\sum \mathrm{X}_{\mathrm{io}} \\
& \mathrm{KSI}_{\mathrm{i}}=\text { kapasitas sentra industri ke- } \mathrm{i} \\
& X_{0}=\text { volume ikan o yang dihasilkan } \\
& \text { lokasi ke-i } \\
& \mathrm{i} \quad=\text { lokasi } \\
& 0 \quad=\text { jenis ikan }
\end{aligned}
$$$$
\text { di mana: }
$$

\section{Score parameter}

Penentapan klasifikasi pelabuhan perikanan diawali dengan penetapan score untuk keempat parameter di atas. Score setiap parameter berkisar mulai dari 0-1. Rumus untuk menghitung score tersebut adalah:

$$
a_{i}=\frac{a_{i}-\min (a)}{\operatorname{Maks}(a)-\min (a)}
$$

di mana:

$$
\mathrm{a}_{\mathrm{i}}=\text { score parameter } \mathrm{j} \text { pada lokasi } \mathrm{i}
$$

\section{Technique for order preference by similarity to ideal solution}

Analisis technique for order preference by similarity to ideal solution adalah teknik pengambilan keputusan yang didasari atas melakukan optimasi. Analisis technique for order preference by similarity to ideal solution bermanfaat dalam melakukan analisis pelelangan serta bermanfaat peningkatan efisiensi (Li \& Xie, 2006). Pada penelitian ini, analisis technique for order preference by similarity to ideal solution dipergunakan untuk melakukan normalisasi data yang dihasilkan dari analisis multi criteria analysis agar diperoleh ranking yang ideal dengan tahapan sebagai berikut:

1. Penyusunan matrik kriteria alternatif:

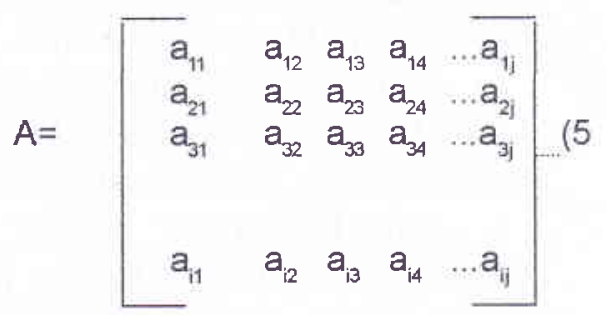

di mana:

$$
\begin{aligned}
a_{i j} & =\text { score parameter } \mathrm{j} \text { pada lokasi } \mathrm{i} \\
\mathrm{j} & =\text { lokasi } \\
j & =\text { parameter }
\end{aligned}
$$

2. Penyusunan matrik $R$ yang merupakan normalisasi matrik A dengan formula:

$$
r_{i j}=a_{i j} / \sqrt{\sum_{i=1}^{m} a_{i j}^{2},} \begin{aligned}
& i=1,2,3, \ldots, m \\
& j=1,2,3, \ldots, n
\end{aligned}
$$

3. Penyusunan matrik $W$ dengan melakukan pembobotan (weighted normalized rating) dengan formula:

$$
\begin{aligned}
V_{i j}=w_{j} r_{i j} ; \quad i & =1,2,3, \ldots, m \\
J & =1,2,3, \ldots, n
\end{aligned}
$$


4. Penyusunan ranking dengan melakukan identifikasi alternatif ideal dan non ideal, menghitung Euclidean distance terhadap solusi ideal dan menghitung relative closeness terhadap matrik $W$.

a. Identifikasi alternatif ideal dan non ideal melalui formula:

$\mid A^{*}=\left\{\left(\right.\right.$ maks $\left.V_{i j} \mid j \varepsilon J_{1}\right),\left(\min V_{i j} \mid j \varepsilon J_{2}\right)$, $i=1,2,3, \ldots, m\}\}=\left\{V_{1}^{*}, V_{2}{ }^{*}, \ldots, V_{n}{ }^{*}\right\}$ $\mid A=\left\{\left(\min V_{i j} \mid j \in J_{1}\right),\left(\right.\right.$ maks $\left.^{2} V_{i j} \mid j \in J_{2}\right)$, $i=1,2,3, \ldots, m\}\}=\left\{V_{1} ; V_{2}, \ldots, V_{n}^{-}\right\}$

b. Menghitung Euclidean distance terhadap solusi ideal melalui formula:

$$
\begin{aligned}
& S^{*}=\left(\sum_{j=1}^{n}\left(V_{i j}-V_{j}^{*}\right)^{2}, i=1,2,3, \ldots, m\right. \\
& S=\left(\sum_{J=1}^{n}\left(V_{i j}-V_{j}\right) 2, i=1,2,3, \ldots, m\right.
\end{aligned}
$$

c. Menghitung relative closeness melalui: $C_{i}^{*}=S_{i}^{-} /\left(S_{i}^{*}+S_{i}^{-}\right), i=1,2,3, \ldots, m$ di mana $0<C_{i}^{*}<1$

\section{HASIL DAN BAHASAN}

Hasil penelitian menunjukan bahwa Pulau Belitung dengan pusatnya di Pelabuhan Perikanan Nusantara Tanjung Pandan ditetapkan sebagai sentra industri dengan klasifikasi penyedia jasa utama dengan score 4 pada analisis multi criteria analysis (Tabel 3) dan merupakan rangking pertama pada analisis technique for order preference by similarity to ideal solution (Tabel 4) dengan nilai random utility value 1. Hal ini menunjukan bahwa prasarana, jumlah kapal perikanan, pasokan faktor input, dan jumlah ikan yang didaratkan merupakan sentra industri terbaik, terlengkap, dan terbanyak produksi ikannya dibandingkan dengan empat sentra di empat pulau lain.

Tabel 3. Scoring analisis multi criteria analysis terhadap indeks pelayanan fasilitas pelabuhan perikanan, indeks kapasitas kapal perikanan, indeks kemandirian, dan kapasitas sentra industri sentra industri perikanan tangkap di Kabupaten Belitung

Table 3. Scoring analysis of multicriteria analysis of the services index of fishing

\begin{tabular}{|c|c|c|c|c|c|}
\hline & IPFP*) & IKAPI & 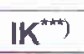 & $\left.K S\right|^{(x+n+1)}$ & Score \\
\hline Belitung & 1,00 & 1,00 & 1,00 & 1,00 & 4,00 \\
\hline Sumedang & 0,04 & 0,00 & 0,00 & 0,00 & 0,04 \\
\hline Seliu & 0,04 & 0,04 & 0,00 & 0,06 & 0,14 \\
\hline Mendanau & 0,07 & 0,31 & 0,04 & 0,30 & 0,72 \\
\hline Gersik & 0,00 & 0,04 & 0,00 & 0,06 & 0,10 \\
\hline
\end{tabular}
port facilities, fishing vessel capacity index, index of independence, and capacity of an industrial center of fishing industry in Belitung District

Keterangan/Remarks: ") Lampiran 1; ") Lampiran 2; "*t) Lampiran 3; "*) Lampiran 4 
Tabel 4. Output analisis technique for order preference by similarity to ideal solution berupa ranking dan klasifikasi sentra industri perikanan tangkap di Kabupaten Belitung

Table 4. Output analysis technique for order preference by similarity to ideal solution in the form of ranking and classification of fishing industry center in Belitung District

\begin{tabular}{clccc}
\hline $\begin{array}{c}\text { Rankingl } \\
\text { Ranking }\end{array}$ & $\begin{array}{c}\text { Sentra industril } \\
\text { Industrial centers }\end{array}$ & $\begin{array}{c}\text { Random utilitas nila/ } \\
\text { Random utility value }\end{array}$ & $\begin{array}{c}\text { Nilai IPFP } \\
\text { dan IKAPI }\end{array}$ & $\begin{array}{c}\text { Klasifikasil } \\
\text { Classification }\end{array}$ \\
\hline 1 & Belitung & 1.00000 & Tertinggi & Penyedia jasa utama \\
2 & Mendanau & 0.20462 & Positif & Penyedia jasa antara \\
3 & Seliu & 0.04046 & Positif & Penyedia jasa antara \\
4 & Gersik & 0.03484 & 0 & Client \\
5 & Sumedang & 0.02020 & 0 & Client \\
\hline
\end{tabular}

Keterangan/Remarks: ${ }^{* * * *)}$ Lampiran 5

Pulau Sumedang mempunyai klasifikasi sebagai client atau feeder dengan score 0,04 dari hasil analisis multi criteria analysis, score 0 pada parameter indeks kapasitas kapal perikanan, ranking terendah pada analisis technique for order preference by similarity to ideal solution dengan nilai RUV 0,02020. Rendahnya output multi criteria analysis dan technique for order preference by similarity to ideal solution menunjukan bahwa kapasitas sentra industri perikanan tangkap di Pulau Sumedang. Nilai 0,04 pada analisis multi criteria analysis diperoleh karena Pulau Sumedang telah dilengkapi dermaga, namun dari segi yang lain yaitu kapasitas kapal perikanan, kemandirian faktor input serta produksi pulau ini yang terkecil.

Pulau Seliu mempunyai klasifikasi sebagai penyedia jasa antara (server atau spoke) dengan score 0,14 , nilai positif pada parameter indeks pelayanan fasilitas pelabuhan perikanan dan indeks kapasitas kapal perikanan, menduduki ranking ketiga dalam analisis technique for order preference by similarity to ideal solution dengan nilai RUV 0,04046. Rendahnya nilai indeks kapasitas kapal perikanan dan kapasitas sentra industri sentra industri ini menunjukan kapasitas kapal perikanan dan ikan yang didaratkan kecil. Nilai nol parameter indeks kemandirian menandakan pasokan faktor input sentra industri ini tergantung pada pasokan dari Pulau Belitung.

Pulau Mendanau mempunyai klasifikasi sebagai penyedia jasa antara (server atau spoke) dengan score 0,72 , nilai positif pada parameter indeks pelayanan fasilitas pelabuhan perikanan dan indeks kemandirian, menempati ranking kedua pada analisis technique for order preference by similarity to ideal solution dengan nilai RUV 0,20462. Rendahnya score indeks pelayanan fasilitas pelabuhan perikanan menunjukan pelayanan fasilitas pelabuhan perikanan Pulau Mendanau sangat minim. Demikian juga halnya dengan rendahnya score indeks kemandirian menunjukan bahwa pasokan faktor input sangat tergantung pada Pulau Belitung.

Pulau Gersik berfungsi sebagai client atau feeder karena mendapatkan score 0,10 , nilai nol pada parameter indeks pelayanan fasilitas pelabuhan perikanan dan indeks kemandirian, serta menempati ranking keempat pada analisis technique for order preference by similarity to ideal solution dengan nilai RUV 0,03484. Nilai nol pada parameter indeks pelayanan fasilitas pelabuhan perikanan menunjukan bahwa 
Pulau Gersik belum memiliki pelayanan fasilitas pelabuhan perikanan. Sedangkan score nol pada parameter indeks kemandirian menunjukan bahwa seluruh faktor input dipasok dari Pulau Belitung.

\section{Status Industri Perikanan Tangkap}

Status industri perikanan tangkap di lokasi studi terpilih diperoleh berdasarkan atas hasil analisis multi criteria analysis dan technique for order preference by similarity to ideal solution. Analisis multi criteria analysis dan technique for order preference by similarity to ideal solution merupakan dua cara analisis untuk pengambilan keputusan yang didasari prinsip optimasi atas beberapa alternatif proyek atau parameter (Montibeller et al., 2006: Li \& Xie, 2006). Analisis multi criteria analysis dan technique for order preference by similarity to ideal solution terhadap empat parameter meliputi indeks pelayanan fasilitas pelabuhan perikanan, indeks kapasitas kapal perikanan, indeks kemandirian, dan kapasitas sentra industri memadai untuk membuat perencanaan makro pembangunan sentra industri berbasis pelabuhan perikanan.

Walaupun analisis multi criteria analysis dan technique for order preference by similarity to ideal solution menghasilkan output sama, namun kedua analisis tersebut memiliki perbedaan yaitu variasi data. Output analisis multi criteria analysis yang diformulasikan menghasilkan variasi data cukup besar. Hasil analisis multi criteria analysis menunjukan variasi score yang cukup besar yaitu 3,96 antara Pulau Belitung sebagai ranking pertama dengan score 4 dengan Pulau Sumedang sebagai ranking kelima dengan score 0,04. Besarnya perbedaan ini menunjukan bahwa perbedaan antar obyek yang diamati berbeda nyata dan penyebaran tidak normal. Dengan hasil ranking yang sama, analisis technique for order preference by similarity to ideal solution menghasil variasi data yang kecil. Pulau Belitung menempati rangking pertama pada analisis technique for order preference by similarity to ideal solution dengan nilai RUV 1, sedangkan Pulau Sumedang yang menempati rangking kelima mempunyai nilai RUV 0,02020. Kecilnya variasi data pada analisis technique for order preference by similarity to ideal solution menunjukan bahwa obyek yang diamati relatif homogen.

Penetapan klasifikasi sentra industri berbasis pelabuhan perikanan dilakukan dengan menggabungkan analisis technique for order preference by similarity to ideal solution dan faktor penting pada analisis multi criteria analysis. Dua faktor penting analisis multi criteria analysis yang dimaksud adalah parameter indeks pelayanan fasilitas pelabuhan perikanan dan indeks kapasitas kapal perikanan. Parameter indeks pelayanan fasilitas pelabuhan perikanan dan indeks kapasitas kapal perikanan disebut faktor penting karena kedua parameter tersebut merupakan pertimbangan utama yang dijadikan pertimbangan usaha dan kapal penangkap ikan melakukan tambat labuh kapal dan keterkaitan kedua faktor tersebut tinggi (Israel \& Rouqe, 2000; Lansot, 1997; Tai \& Hwang. 2005).

\section{Klasifikasi Sentra Industri Perikanan Tangkap dan Pengembangannya}

Pembangunan perikanan tangkap di Kabupaten Belitung, telah sesuai dengan konsep jaringan industri perikanan tangkap. Pulau Belitung dengan pusatnya di Pelabuhan Perikanan Nusantara Tanjung Pandan difokuskan sebagai pelayanan jasa utama. Dalam mewujudkan tujuan tersebut, pemerintah daerah tengah melengkapi pulau ini dengan pelabuhan kontainer dengan luas 50 ha terletak di daerah 
Pegantungan, Kecamatan Membalong. Pembangunan pelabuhan kontainer di Pegantungan berdampak pada mudahnya akses transportasi faktor asupan dan variabel keluaran sehingga dapat menekan biaya transportasi. Di samping itu, Pulau Belitung memiliki kawasan pertumbuhan pengolahan ikan yang dijadikan yang terletak di Desa Tanjung Binga, Kecamatan Sijuk. Kawasan pengolahan ikan Tanjung Binga merupakan sentra pengolahan ikan di Kabupaten Belitung telah dilengkapi dengan sumber energi matahari sebagai suplemen energi ruang proses (processing room), cold storage, dan ruang pembeku (freezing room).

Pulau Mendanau dengan pusatnya di Pusat Pendaratan Ikan Selat Nasik berfungsi sebagai penyedia jasa antara atau server dengan kapasitas produksi 11.000 ton/tahun. Untuk mewujudkan klasifikasi server tersebut, Pelabuhan Perikanan Pantai Selat Nasik telah dilengkapi dengan pabrik es berkapasitas 5 ton/hari dan ruang penyimpanannya. Energi listrik pabrik es ini berasal dari energi matahari dan energi diesel yang disebut dengan pembangkit listrik tenaga hibrid. Dengan memanfaatkan pembangkit listrik tenaga hibrid ini, biaya pembuatan es dapat ditekan. Namun kapasitas pabrik es dan ruang penyimpanan yang tersedia tersebut belum mencukupi kebutuhan. Untuk itu perlu dibangun pabrik es dengan kapasitas empat kali lipat. Dengan kapasitas 11.000 ton/tahun, Pulau Mendanau tidak mampu menampung semua produksi dari daerah client (total produksi client dan sekitarnya kurang lebih 17.000 ton/tahun) sehingga sebagian dari produksi daerah client dipasarkan langsung ke Pulau Belitung dan pasar regional. Kendala yang dihadapi sekarang ini adalah belum tersedianya pasokan faktor asupan, keterbatasan penampungan bahan bakar minyak, dan energi listrik.
Pulau Seliu yang menempati rangking ketiga berfungsi sebagai penyedia jasa antara. Pulau terbesar nomor tiga di Kabupaten Belitung dapat dikembangkan sebagai pangkalan armada penangkapan ikan dengan kapasitas mencapai 5.000 ton/ tahun. Pangkalan armada layak dikembangkan mengingat terdapat dua alternatif moda transportasi yang mungkin dibangun yaitu transportasi laut ke Pelabuhan Perikanan Nusantara Tanjung Pandan dan gabungan moda transportasi laut ke wilayah terdekat di Pulau Belitung yang dipadukan dengan moda transportasi darat ke Pelabuhan Perikanan Nusantara Tanjung Pandan. Prasarana minimal yang perlu dibangun adalah pabrik es mini di mana merupakan salah satu prasyarat rantai dingin. Pembangunan pabrik es ini sangat memungkinkan mengingat pada saat ini telah mulai banyak penampung ikan di pulau ini.

Pulau Sumedang dan Pulau Gersik yang mempunyai klasifikasi sebagai client (sumber pasokan ikan) diupayakan dapat melakukan pengelolaan perikanan tangkap yang berkelanjutan. Beberapa hal yang perlu dilakukan di kedua pulau ini adalah menjaga ekosistem perairan serta pengendalian volume penangkapan ikan.

\section{KESIMPULAN}

1. Pulau Belitung dengan pusatnya di Pelabuhan Perikanan Nusantara Tanjung Pandan berklasifikasi sebagai penyedia jasa utama, Pulau Mendanau dengan pusatnya di Pusat Pendaratan Ikan Selat Nasik dan Pulau Seliu, berklasifikasi sebagai penyedia jasa antara server dan Pulau Sumedang dan Pulau Gersik berklasifikasi sebagai client.

2. Klasifikasi pelabuhan perikanan dalam suatu jaringan industri berimplikasi pada 
peningkatan efektivitas dan efisiensi pembangunan pelabuhan perikanan tangkap sebagai sentra industri perikanan tangkap.

3. Penelitian ini berimplikasi agar kebijakan pembangunan pelabuhan perikanan tangkap sebagai sentra industri perikanan tangkap memperhitungkan hubungan jaringan industri dan melaksanakan kebijaksanaan tersebut secara konsekuen.

\section{DAFTAR PUSTAKA}

Direktorat Jenderal Perikanan Tangkap. 2008. Perikanan Tangkap Indonesia dari Masa ke Masa untuk Kesejahteraan Bangsa. Direktorat Jenderal Perikanan Tangkap. Departemen Kelautan dan Perikanan. Jakarta. 216 pp.

Hadi, S. E. \& M. Moron. 2007. Cross Border Cooperation Between Seaport. The Case of the Strait of Gibratar. 43 pp.

Israel, D. C. \& R. M. G. R. Roque. 2000. Analysis of Fishing Ports in the Philipines. Manila: Philipine Institute of Development Studies. 60 pp.

Lansot, G. G. 1997. New trends in planning and management of fishing port facilities. Buletin of Institute of Fisheries Research. Nomor 15.
Li, H. \& Q. S. Xie. 2006. Application of TOPSIS in the Bidding Evaluation of Manufacturing Enterprises. Proceeding of e-ENGDET 2006. Guiyang. China. 184-188.

Montibeller, G., H. Gummer, \& D. Tumidei. 2006. Combining Scenario Planning and Multi Criteria Decision Analysis in Practice. Journal of Multi Criteria Decision Analysis. London. Wiley Inter Science. Anal. 14: 5-20.

Robinson, S. 2003. A Study of Gloucester's Commercial Fishing Infrastrucure. New England: Interim Report. 47 pp.

Tai, H. H. \& C. C. Hwang. 2005. Analysis of HUB Port Choice for Container Trunk Lines in East Asia dalam Journal of the Eastern Asia Society for Transportation Studies. 6: 907-919.

Yang, S. Y., K. J. Bun, \& M. S. Kang. 2005. Introduction of Pusan New Port ProjectHUB Port in Northeast Asia dalam Proceeding of the Fifteenth International Offshore and Polar Engineering Conference dalam the International Society of Offshore and Polar Engineers. ISBN 1-880653-64-8; ISSN 1098-6189.

Wang, M. 2007. Port Cooperation and Competition in Korea, China, and Japan; From the Perspective of Shipping Network and Port Development. 41 pp. 
Lampiran 1. Indeks pelayanan fasilitas pelabuhan perikanan Appendix 1. Service index of fishing port facilities

\begin{tabular}{lcccccccc}
\hline & $\begin{array}{c}\text { Dermagal } \\
\text { Pier }\end{array}$ & TPI & BBM dan APMS & $\begin{array}{c}\text { Pabrik es/ } \\
\text { Ice factory }\end{array}$ & Coldstorage & $\begin{array}{c}\text { Jumlah/ } \\
\text { Total }\end{array}$ & IPFP & Score \\
\hline Belitung & 18 & 1 & 9 & 7 & 6 & 41 & 11,96 & 1,00 \\
Sumedang & 1 & 0 & 0 & 0 & 0 & 1 & 0,45 & 0,04 \\
Seliu & 1 & 0 & 0 & 0 & 0 & 1 & 0,45 & 0,04 \\
Mendanau & 1 & 1 & 1 & 1 & 0 & 4 & 0,87 & 0,07 \\
Gersik & 0 & 0 & 0 & 0 & 0 & 0 & 0,00 & 0,00 \\
\hline Jumlah & $\mathbf{2 1}$ & $\mathbf{2}$ & $\mathbf{1 0}$ & $\mathbf{8}$ & $\mathbf{6}$ & $\mathbf{4 7}$ & & \\
\hline Bobot & $\mathbf{0 , 4 5}$ & $\mathbf{0 , 0 4}$ & $\mathbf{0 , 2 1}$ & $\mathbf{0 , 1 7}$ & $\mathbf{0 , 1 3}$ & & & \\
\hline
\end{tabular}

Lampiran 2. Indeks kapasitas kapal perikanan Appendix 2. Index capacity of fishing boats

\begin{tabular}{|c|c|c|c|c|c|c|}
\hline \multirow{2}{*}{ No. } & \multirow{2}{*}{$\begin{array}{l}\text { Lokasil } \\
\text { Location }\end{array}$} & \multirow{2}{*}{$\begin{array}{c}<5 \text { GT } \\
C_{k}=0,3\end{array}$} & \multirow{2}{*}{$\begin{array}{c}5-10 \mathrm{GT} \\
\mathrm{C}_{\mathrm{k}}=0,5\end{array}$} & \multirow{2}{*}{$\begin{array}{c}\geq 10 \mathrm{GT} \\
\mathrm{C}_{\mathrm{k}}=1\end{array}$} & \multirow{2}{*}{ IKAPI } & \multirow{2}{*}{ Score } \\
\hline & & & & & & \\
\hline 1. & Pulau Belitung & 1,192 & 126 & 1 & 446,8 & 1,00 \\
\hline 2. & Pulau Gersik & 106 & 0 & 0 & 31,8 & 0,04 \\
\hline 3. & Pulau Mendanau & 396 & 33 & 7 & 148,9 & 0,31 \\
\hline 4. & Pulau Sumedang & 42 & 0 & 0 & 12,6 & 0,00 \\
\hline 5. & Pulau Seliu & 92 & 5 & 0 & 31,1 & 0,04 \\
\hline
\end{tabular}

Lampiran 3. Indeks kemandirian

Appendix 3. Index of independence

\begin{tabular}{|c|c|c|c|c|c|c|c|}
\hline & $\begin{array}{c}\text { Kebutuhan } \\
\text { bahan bakar } \\
\text { minyak/ } \\
\text { Fuel oil } \\
\text { supplies (L) }\end{array}$ & $\begin{array}{l}\text { Pasokan } \\
\text { bahan } \\
\text { bakar } \\
\text { minyak/ } \\
\text { Supply of } \\
\text { fuel oil }\end{array}$ & $\begin{array}{c}\text { Indeks } \\
\text { kemandirian/ } \\
\text { Index of } \\
\text { independence }\end{array}$ & $\begin{array}{c}\text { Kebutuhan } \\
\text { es/ } \\
\text { Needs ice }\end{array}$ & $\begin{array}{l}\text { Pasokan } \\
\text { es/ } \\
\text { Supply } \\
\text { ice }\end{array}$ & $\begin{array}{c}\text { Indeks } \\
\text { kemandirian/ } \\
\text { Index of } \\
\text { independence }\end{array}$ & Score \\
\hline Belitung & 9.431 .766 & 20.520 .000 & 2,18 & 22.940 & 37.800 & 1,65 & 1,00 \\
\hline Sumedang & 332.327 & 0 & 0,00 & 4.426 & & 0,00 & 0,00 \\
\hline Seliu & 727.955 & 0 & 0,00 & 5.145 & & 0,00 & 0,00 \\
\hline Mendanau & 3.133 .372 & 600.000 & 0,19 & 12.645 & 900 & 0,07 & 0,04 \\
\hline \multirow[t]{2}{*}{ Gersik } & 838.731 & 0 & 0,00 & 6.916 & & 0,00 & 0,00 \\
\hline & 14.464 .152 & 21.120 .000 & & 52.072 & 38.700 & & \\
\hline
\end{tabular}

Lampiran $4 . \quad$ Kapasitas sentra industri

Appendix 4. The capacity of an industrial

\begin{tabular}{ccccclcc} 
No. & Lokasi/Location & KSI & Score & No. & LokasilLocation & KSI & Score \\
\hline 1. Pulau Belitung & $22.940,91$ & 1,00 & 4. & Pulau Sumedang & $2.213,29$ & 0,00 \\
2. Pulau Gersik & $3.458,08$ & 0,06 & 5. Pulau Seliu & $3.429,97$ & 0,06 \\
3. Pulau Mendanau & $8.429,75$ & 0,30 & & & & \\
\hline
\end{tabular}


Lampiran 5. Analisis technique for order preference by similarity to ideal solution Appendix 5. Analysis of technique for order preference by similarity to ideal solution

\begin{tabular}{|c|c|c|c|c|}
\hline \multirow{2}{*}{ Input data set: } & $\operatorname{Max}$ & $\operatorname{Max}$ & Max & Max \\
\hline & IPFP & IKAPI & IK & KSI \\
\hline Belitung & 1 & 1 & 1 & 1 \\
\hline Sumedang & 0,04 & 0 & 0 & 0 \\
\hline Seliu & 0,04 & 0,04 & 0 & 0,06 \\
\hline Mendanau & 0,07 & 0,31 & 0,04 & 0,3 \\
\hline Gersik & 0 & 0,04 & 0 & 0,06 \\
\hline Weights & 0,25000 & 0,25000 & 0,25000 & 0,25000 \\
\hline \multicolumn{5}{|c|}{ Modified input data set: } \\
\hline & $\operatorname{Max}$ & $\operatorname{Max}$ & Max & Max \\
\hline & IPFP & IKAPI & IK & KSI \\
\hline Belitung & 1 & 1 & 1 & 1 \\
\hline Sumedang & 0,04 & 0 & 0 & 0 \\
\hline Seliu & 0,04 & 0,04 & 0 & 0,06 \\
\hline Mendanau & 0,07 & 0,31 & 0,04 & 0,3 \\
\hline Gersik & 0 & 0,04 & 0 & 0,06 \\
\hline Weights & 0,25000 & 0,25000 & 0,25000 & 0,25000 \\
\hline \multicolumn{5}{|c|}{ Normalised criterion matrix $R$ : } \\
\hline & $\operatorname{Max}$ & $\operatorname{Max}$ & Max & Max \\
\hline & IPFP & IKAPI & IK & KSI \\
\hline Belitung & 0,99597 & 0,95377 & 0,99920 & 0,95468 \\
\hline Sumedang & 0,03984 & 0,00000 & 0,00000 & 0,00000 \\
\hline Seliu & 0,03984 & 0,03815 & 0,00000 & 0,05728 \\
\hline Mendanau & 0,06972 & 0,29567 & 0,03997 & 0,28640 \\
\hline Gersik & 0,00000 & 0,03815 & 0,00000 & 0,05728 \\
\hline Weights & 0,25000 & 0,25000 & 0,25000 & 0,25000 \\
\hline
\end{tabular}

Weighted criterion matrix W:

\begin{tabular}{|c|c|c|c|c|c|c|c|}
\hline & Max & Max & Max & $\operatorname{Max}$ & \multirow{2}{*}{ dit } & \multirow{2}{*}{ di- } & \multirow{2}{*}{$\mathrm{Ci}$} \\
\hline & IPFP & IKAPI & IK & KSI & & & \\
\hline Belitung & 0,24899 & 0,23844 & 0,24980 & 0,23867 & 0,00000 & 0,48807 & 1,00000 \\
\hline Sumedang & 0,00996 & 0,00000 & 0,00000 & 0,00000 & 0,48307 & 0,00996 & 0,02020 \\
\hline Seliu & 0,00996 & 0,00954 & 0,00000 & 0,01432 & 0,47145 & 0,01988 & 0,04046 \\
\hline Mendanau & 0,01743 & 0,07392 & 0,00999 & 0,07160 & 0,40757 & 0,10485 & 0,20462 \\
\hline Gersik & 0,00000 & 0,00954 & 0,00000 & 0,01432 & 0,47658 & 0,01721 & 0,03484 \\
\hline Weights & 0,25000 & 0,25000 & 0,25000 & 0,25000 & & & \\
\hline Ideal & 0,24899 & 0,23844 & 0,24980 & 0,23867 & & & \\
\hline Basal & 0,00000 & 0,00000 & 0,00000 & 0,00000 & & & \\
\hline
\end{tabular}

Final ranking:

\begin{tabular}{clcclc} 
Ranking & $\begin{array}{c}\text { Sentra industri/ } \\
\text { Industrial centers }\end{array}$ & $\begin{array}{c}\text { Random utility } \\
\text { value/Random } \\
\text { utilitas nilai }\end{array}$ & Ranking & $\begin{array}{c}\text { Sentra industri/ } \\
\text { Industrial centers }\end{array}$ & $\begin{array}{c}\text { Random utility } \\
\text { valuelRandom } \\
\text { utilitas nilai }\end{array}$ \\
\hline 1 & Belitung & 1,00000 & 4 & Gersik & 0,03484 \\
2 & Mendanau & 0,20462 & 5 & Sumedang & 0,02020 \\
3 & Seliu & 0,04046 & & & \\
\hline
\end{tabular}

